\title{
THE EFFECTIVENESS OF MACROPRUDENTIAL POLICIES IN MITIGATING THE SYSTEMIC RISK IN INDONESIA
}

\author{
Muh. Imaduddin Akbar', Muhammad Ghafur Wibowo² \\ 1,2Department of Sharia Economic, Sunan Kalijaga Yogyakarta State Islamic University, \\ Yogyakarta \\ Email: imaduddinakbar3@gmail.com (corresponden)
}

\begin{abstract}
This study aims to investigate the effectiveness of macroprudential policies in mitigating the systemic risk in Indonesia. The study uses quantitative descriptive analysis with the Vector Error Correction Model (VECM) and emphasizes on the impact of two macroprudential instruments applied in Indonesia; Macroprudential Liquidity Buffer (MLB) and Countercyclical Capital Buffer (CCyB) to credit growth for conventional and financing growth for Sharia bank. This study employes monthly data over the periods M1 2010 to M10 2019 that obtained from Bank Indonesia's (BI) website (www.bi.go.di) and the data published monthly by Financial Service Authority (OJK); Indonesia Bank Statistic and Sharia Bank Statistic.

The result indicates that MLB has a positive impact on credit growth and negative effect financing for Sharia Bank. Otherwise, CCyB shows the opposite results, where it has a negative effect on credit growth, while in the Sharia bank, CCyB has a positive effect. Therefore, it is sufficient to conclude that MLB has a capability to curb the systemic risk for Sharia bank, whereas CCyB is effective for conventional bank.
\end{abstract}

Keywords: Macroprudential, MLB, CCyB, Systemic Risk. 


\section{Introduction}

\section{Background}

Historically, Indonesia experienced two financial crises. First, Asia Financial Crises in 1998, where Indonesia, Thailand, and South Korea were the three most fragile countries. Second, Global Financial Crises in 2008, occurring widely in property sector in USA. However, Indonesia has a more resilient performance amid the uncertainty of global economics at that time.

The crises provide essential lessons for the government to concern about the prudent aspect of every taken policy. Hahm et al. (2012) explained several lessons in financial crises. The risk build-up has significant impact on real economy, very high cost and price and output stability do not ensure financial security. In spite of the high cost needed, financial crises also need long time recovery (Bank Indonesia 2016).

The financial crises mostly originated from economic instability. Policymakers attempt on their authorities to arrange the most delicate instruments to attain stability. On the other hand, they also admire that there are no fundamentals instruments to intervene the crises. The existing tools, whether microprudential, monetary, and fiscal instruments, do not always suffice to assure financial stability even it conducted adequately and effectively in their ways (Claessens 2014).

To deal with such conditions, the government and related authorities attempt to construct new prudent instrument that assists the policymaker in mitigating the systemic risk. The macroprudential policies get promoted increasingly by regulatory and supervisor, especially from the Bank of International Settlement (BIS). A broader agreement on its relevance has been reached as a result of the late-2000s financial crises.

Several studies showed that macroprudential policies are valid and useful instrument to prevent financial crises. According to IMF (2011), macroprudential policies aimed to maintain financial stability to limit systemic risk or system-wide financial risk. Shi, Jou, \& Tripe (2014) stated that macroprudential policy is an attractive instrument to mitigate excessive credit growth. Macroprudential policies could address the cyclical vulnerabilities in systemic risk by slowing credit growth in good times and boosting the credit in bad times (Jimenez et al. 2012).

The macroprudential policy mostly implemented in emerging markets. It was predicated on the fragility of financial institutions and still need to deepen on financial instruments. The policy in the emerging market is more relevant and pressing than usual (Hahm et al. 2012). Claessens et al. (2014) conducted research in 2800 banks in 48 countries over periods 2000-2010, they found that emerging 
markets countries use macroprudential policies relatively more than advanced countries and it work better, perhaps as their financial system is less liberalized, allowing combination policies to be used.

Bank Indonesia has the authority to take control of macroprudential policies in Indonesia. The institution applied the accommodative approach to smooth the credit cycles. Bank Indonesia recently promoted new instrument, named Macroprudential Liquidity Buffer (MLB) where it based on countercyclical liquidity and time-varying. Bank Indonesia Assistant Governor, Filianingsih Hendarta stated that this is an improvement instrument from previous instruments. It is expected to be able to overcome the bank liquidity issues (Asmara 2018).

According to Bank Indonesia (2018), MLB is a part of the macroprudential policy to prevent and minimize the systemic risk and the shock on the banking system. This instrument is countercyclical to the economic cycle so that it can be adapted to changing economic and financial conditions.

As the new instrument, the effectiveness of Macroprudential Liquidity Buffer in mitigating systemic risk is untested. As for another device, the study still shows mix in results. Purnawan \& Nasir (2015) and Sakti et al. (2018) showed that Reserve Requirement Plus Fund to Deposit Ratio is sufficient to increase the credit growth whereas Dana (2018) concluded the opposite results where the implementation of the similar policy is capable of countering the credit cyclical and credit mitigation. Therefore, this study is designed to dig deeply on the effectiveness of macropudential policies to dual banking concept, commercial and Sharia Bank in Indonesia.

\section{Objectives}

Specifically, the study attempts to attain this following study:

1. Finding out the Impact of Macroprudential Liquidity Buffer and Countercyclical Capital Buffer on the credit and financing growth in Indonesia.

2. Providing proper policies in mitigating the systemic risk for Conventional and Sharia Bank in Indonesia.

\section{Literature Review}

\section{Background Theory}

Systemic risk has a capability for instability as a result of contagion in some or all financial systems. The interaction determines the size factors, the complexity of the business, the cooperation between institutions, and all financial markets (interconnectedness). Behavioral tendency is overdoing it from conventional actors or institutions to follow the economic cycle (procyclicality) (Harun, Rachmanira, and 
Renanda 2015).

Blancher et al. (2013) defined the systemic risk as the likelihood that originated within, or spread through, the financial sector with the potential for several adverse effects on financial intermediation and real output. Theoretical and empirical models dealing with interactions between the financial industry and the real economy, as well as between cross-border transmission channels, are useful for monitoring purposes in general:

a. Build-up phase, systemic risk builds up over periods and can reflect several underlying reasons. The financial system may have a high signal to fragile sectors, and be subject to increase risk-taking (e.g., due to competition for market share or lax supervision), including through financial innovation. During this phase, systemic risk measures could focus on assessing the likelihood of systemic risk, taking into account the evolving balance between potential financial losses an existing buffer designed to absorb these failures.

b. Shock materialization, this phase is the beginning. Excessive risk-taking makes the financial system fragile and susceptible to an exogenous shock. Thus, systemic risk measurement could focus primarily on assessing potential defaults in both the financial system and the real economy sector.

c. Amplification and propagation, in most crises, shocks affect the broader system, including financial institutions, markets, and other sectors (and potentially other countries' financial systems). At that point, systemic risk measurement could focus on amplification mechanisms, such as interconnections between financial institutions, potential fire sales of financial assets, as well as cross-border exposures and the related adverse feedback loops.

Bank Indonesia (Bank Indonesia 2016) explained that the potential impact of systemic risk could disrupt economic activity as a whole. It caused by interconnectedness between elements of the financial system raises the potential for the spread of the risk (contagion effect). Thus, the systemic risk is not only originated from the financial institutions but also generated from the real economic activity.

The term macroprudential policy was first known in late 1979 in an unpublished document of the Cooke Committee (the precursor of the Basel Committee on Banking Supervision) and the Bank of England. But only in the early 2000s, after recurrent two financial crises affected the world economy.

The macroprudential policy was accessible post-crises in 2008. The crises triggered by the subprime mortgage transmit the negative effect on the world economy, and most often, in emerging markets, including Indonesia. It encourages the G20 countries' leader and related authority to construct the macroprudential framework. As a further proceeding, the central banks and all financial power 
attempts to develop the macroprudential approach to maintain financial stability (Bank Indonesia 2016).

According to the IMF (IMF 2011), macroprudential policy can interact with different types of public policy impacting on financial stability. The macroprudential system seeks to address two specific dimensions of systemic risk, time dimension, and cross-sectional dimension.

a. The time dimension reflects a cumulative, amplifying mechanism that operates within the financial system, as well as between the financial system and the real economy. This mechanism, or procyclicality, is based on a collective tendency by economic agents, both financial and non-financial, to increase risk exposures during the boom phase of a business cycle and to become overly risk-averse during the bust-phase.

b. The cross-sectional dimension reflects the distribution of risk in the financial system at a given point in time. If procyclicality sets the destabilizing mechanism in motion, the cross-sectional dimension provides a further impetus and magnifies the impact of financial distress. Distress may also arise as a result of severe problems without a build-up of weaknesses over time. It depends on the size, concentration, substitutability, and the interconnectedness between them. Linkages could arise due to intra-firm exposures (assets, funding) or their vulnerability to standard shocks that create prime channels of contagion through spillovers between institutions.

The lesson from 2008 showed Bank Indonesia played a significant role in systemic risk, it could be the identification of the systemic risk or provide the emergence of risk potential. Bank Indonesia is an appropriate institution to take control of the macroprudential policy. Several reasons why Bank Indonesia has authority on it; Bank Indonesia as a Lender of Last Resort (LoLR), Bank Indonesia as the monetary authority, Bank Indonesia as payment system authority, Bank Indonesia has an institutional knowledge and expertise in assessing the systemic risk, and Bank Indonesia has a capacity to construct the policy mix comprehensively.

\section{Previous Studies}

The effectiveness of macroprudential policies was previously revealed in several studies. Fendoglu (2017) stated in his research that macroprudential tools help smooth the credit cycles in an economically and statistically significant way. Sakti et al. (Sakti et al. 2018) revealed that credit growth is positively affected by GDP and negatively affected by BI Rate and inflation. Credit growth also affected by deposit funds and default rate ratio. Interestingly, there is a different impact of capital buffer instruments on credit growth. Capital buffer instrument has negatively affected the 
financing growth of Islamic banks in Indonesia.

Dana (Dana 2018) depicted that the LTV instruments can reduce credit growth but not to procyclical mitigation. Dissimilar results in the implementation of CCB, and GWM + LDR instruments are capable of procyclical credit mitigation. While Ubaidillah (2019) conclude that FTV/LTV hurts credit and financing; in other words, this policy is effective in mitigating the excess in credit and funding. Reserve Requirement+LDR also showed the same result,it is useful for countercyclical credit growth. However, RR+FDR has a positive impact on financing, and it can be concluded that Reserve Requirement+FDR is not effective in mitigating the financing growth.

Puspitasari (2016) showed that the impact of Reserve Requirement + LFR policy neither in Conventional Bank or Sharia Bank is low. These policies have not been effective in mitigating the procyclicality. The LTV/FTV also showed a similar result, which is the contribution of this policy is low in the dual system bank. Nevertheless, the instruments cannot stand alone in mitigating the procyclicality. It needs the monetary policy to attain financial stability.

\section{Research Methods}

\section{Data}

The study uses secondary data obtained from Indonesia Banks Statistic and Sharia Bank Statistic published by Financial Service Authority (OJK). It runs monthly data over the periods M12010-M102019. The data type is time-series, and the EViews 10 software package were used as the data processor. Unit analysis includes all conventional and sharia banks in Indonesia as we run the credit growth variables as the dependent variables while two macroprudential variables, MLB (X1) and CCyB (X2) are measured as the dummy variables. The macroeconomic and internal bank variables; Inflation (X3), BI 7-Day RRR (X4), NPL (X5), and CAR (X6); are the independent variables that expected to affect credit and financing growth.

Table 1. Operational Variables

\begin{tabular}{|c|c|c|c|}
\hline No & Variable & Description & Calculation \\
\hline \multicolumn{4}{|c|}{ Measurement of the Effectivess of Macroprudential Policies } \\
\hline 1 & $\begin{array}{l}\text { Credit Growth } \\
\qquad\left(Y_{1}\right)\end{array}$ & $\begin{array}{l}\text { Contractual agreement in which } \\
\text { borrowers receive something of value } \\
\text { now and agrees to pay it back to the } \\
\text { lender with some interest. }\end{array}$ & $=\frac{\text { Credit } t-\text { Credit } t-1}{\text { Credit } t-1} \times 1$ \\
\hline 2 & $\begin{array}{l}\text { Financing Growth } \\
\text { (Y2) }\end{array}$ & $\begin{array}{c}\text { Contractual agreement in which } \\
\text { borrower receives something of value } \\
\text { now and agrees to reimburse to } \\
\text { lender with return from profit-loss } \\
\text { sharing scheme. }\end{array}$ & $=\frac{\text { Financ } t-\text { Financ } t-1}{\text { Financ } t-1} x$ \\
\hline
\end{tabular}




\begin{tabular}{|c|c|c|c|}
\hline 3 & MLB (X1) & $\begin{array}{l}\text { MLB is a minimum liquidity buffer that } \\
\text { should be kept by bank in the form of } \\
\text { specific securities. }\end{array}$ & - \\
\hline 4 & ССуВ (X2) & $\begin{array}{c}\text { CCyB is a mandatory capital that } \\
\text { financial institutions are required to } \\
\text { hold as an addition to other minimum } \\
\text { capital requirements. }\end{array}$ & - \\
\hline 5 & Inflations (X3) & $\begin{array}{c}\text { Inflation is a quantitative } \\
\text { measurement of the rate at which } \\
\text { level the average of good and service } \\
\text { price in the economy over specific } \\
\text { periods. }\end{array}$ & $=\frac{I H K_{n}-I H K_{n-1}}{I H K_{n-1}} X 100 \%$ \\
\hline 6 & BI 7-DRRR (X4) & $\begin{array}{l}\text { BI 7-Day RRR is a reference rate } \\
\text { announced by Bank Indonesia that } \\
\text { reflects monetary policy stance. }\end{array}$ & - \\
\hline 7 & NPL/NPF (X5) & $\begin{array}{c}\text { NPL or NPF is a sum of borrowed } \\
\text { money upon which the debtors have } \\
\text { not made the scheduled payment for } \\
\text { a specific period. }\end{array}$ & $=\frac{\text { Total NPL, NPF }}{\text { Total Credit, Fin }} \times 100 \%$ \\
\hline 8 & CAR (X6) & $\begin{array}{l}\text { CAR is a measurement of bank } \\
\text { available capital expressed as a } \\
\text { percentage of bank's risk-weighted } \\
\text { credit exposure. }\end{array}$ & $=\frac{\text { Capital }}{\text { Risk Weighted Assets }} \times 1$ \\
\hline
\end{tabular}

\section{Model Development and Method}

This study uses A Vector Auto Regression (VAR) model to analyze the data. VAR models in economics were made accessible by Sims (1980). This model is useful when one is interested in predicting multiple time series variables using a single model. VAR model is an extension of the univariate autoregression (AR), where it creates an interplay vector. The Vector Autoregression model is one of the most successful, flexible, and easy to use models to analyze multivariate time-series. The VAR/VECM model has proven to be especially useful for describing the dynamic behavior of economic and financial time series and for forecasting.

Commonly, the simple VAR/VECM model is given by the equation below:

$$
Y_{t}=a+A_{1} Y_{t-1}+A_{2} Y_{t-2} \cdots+A_{p} Y_{t-p}+\varepsilon_{t}
$$

Where:

$Y_{t}=\left(Y_{1 t} Y_{2 t}, \ldots Y_{n t}\right)$ : vector of time series variable

$a:$ an (nx1) vector of Intercept

$A_{1}(i=1,2, \ldots p)$ : $(\mathrm{nx})$ coefficient of matrices

$\varepsilon_{t}$ : an (nx1) vector of unobservable i.i.d zero mean error term (white noise)

This research will examine seven variables and possibilities of having causality. The existing research also implemented the VAR model constructed above, such as Fauziyyah (2016) and Ubaidillah (Ubaidillah 2019). This question gives the 
mathematics model of this study.

The model for Conventional Banks:

$$
\begin{aligned}
\Delta \text { CrGrowth }_{t}= & C_{1}+\sum_{t=1}^{k-1} a_{1} \text { CrGrowthy }_{t-1}+\sum_{t=1}^{k-1} a_{1} \text { MLB }_{t-1}+\sum_{t=1}^{k-1} a_{1} C C y B_{t-1} \\
& +\sum_{t=1}^{k-1} a_{1} \text { BIFDRR }_{t-1}+\sum_{t=1}^{k-1} a_{1} \text { Inflasi }_{t-1}+\sum_{t=1}^{k-1} a_{1} N P L_{t-1} \\
& +\sum_{t=1}^{k-1} a_{1} \text { CAR }_{t-1}+\lambda E C T_{t}+U_{t}
\end{aligned}
$$

The model for Sharia Banks:

$$
\begin{aligned}
\text { FinGrowt }_{t}= & C_{1}+\sum_{t=1}^{k-1} a_{1} \text { FinGrowthy }_{t-1}+\sum_{t=1}^{k-1} a_{1} M L B_{t-1}+\sum_{t=1}^{k-1} a_{1} \text { CCyB }_{t-1} \\
& +\sum_{t=1}^{k-1} a_{1} \text { BITDRRR }_{t-1}+\sum_{t=1}^{k-1} a_{1} \text { Inflasi }_{t-1}+\sum_{t=1}^{k-1} a_{1} N P F_{t-1} \\
& +\sum_{t=1}^{k-1} a_{1} C_{t} A R_{t-1}+\lambda E C T_{t}+U_{t}
\end{aligned}
$$

According to Widarjono (2013), he demonstrates the steps to test the VAR model which is start with stationary test, lag length selection, VAR stability, Granger Causality, Cointegration, VAR estimation, Impulse Response Function (IRF), and Variance Decomposition (VD).

First, we conduct stationarity test, the time series is considered to be stationary if its statistical properties do not vary with time (expectation, variance, and autocorrelation). A stationary test allows the system verifying whether a series is stable or not. There are two different approaches to measure them; stationary analysis such as the KPPS test and unit-roots tests, such as the Dickey-Fuller (DF) test and its augmented version. This study will use the ADF test and PP test, and the formula of the ADF test is given below:

$$
\begin{aligned}
& \Delta Y_{t}=\gamma Y_{t-1}+\sum_{1=2}^{p} \beta_{i} \Delta Y_{t-1+1}+\varepsilon_{t} \\
& \Delta Y_{t}=\alpha_{0}+\gamma Y_{t-1}+\sum_{i-2}^{p} \beta_{i} \Delta Y_{t-1+1}+\varepsilon_{t} \\
& \Delta Y_{t}=\alpha_{0}+\alpha_{1} T+\gamma Y_{t-1}+\sum_{i=2}^{p} \beta_{i} \Delta Y_{t-1+1}+\varepsilon_{t}
\end{aligned}
$$

Where: $Y=$ observed variable

$$
\begin{aligned}
& \Delta Y_{t}=Y_{t}-Y_{t-1} \\
& T=\text { time trends }
\end{aligned}
$$

Then, we conduct the lag length for the VAR model that may be determined by using model selection criteria. The general approach is to fit VAR models with orders $p=0, \ldots, P_{\max }$ And choose the value of $\mathrm{p}$, which minimizes some model 
selection criteria. The three most common information criteria are the Akaike (AIC), Schwarz-Bayesian (BIC), and Hannan-Quinn (HQ):

$$
\begin{aligned}
& \Delta Y_{t}=\gamma Y_{t-1}+\sum_{1=2}^{p} \beta_{i} \Delta Y_{t-1+1}+\varepsilon_{t} \\
& \Delta Y_{t}=\alpha_{0}+\gamma Y_{t-1}+\sum_{i-2}^{p} \beta_{i} \Delta Y_{t-1+1}+\varepsilon_{t} \\
& H Q(p)=-2\left(\frac{i}{T}\right)+2 k \log \left(\frac{\log (T)}{T}\right)
\end{aligned}
$$

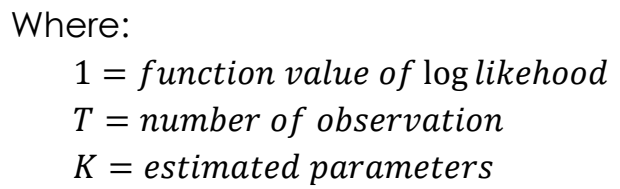

The hypothesis from any non-stationary ( $1^{\text {st }}$ level) time-series will bias and misleading the result. Then, these series have to be analyzed with different method, called the cointegration test. When $X_{t}$ and $Y_{t}$ are $I(1)$ and if there is a $\theta$ such that $Y_{t}-\theta X_{t}$ is $I(0), X_{t}$ and $Y_{t}$ are considered as cointegrated. Put differently, cointegration of $X_{t}$ and $Y_{t}$ means that $X_{t}$ and $Y_{t}$ have the same or a common stochastic trend, and it can be eliminated by taking a specific difference of the series such as resulting sequence is stationary.

The cointegration test identifies the stable, long-run relationship between sets of variables. However, if the test fails to find such a link, it is not proven that one does not exist; it only suggests that one does not exist. There are three most popular test; Engle-Granger test, Phillips-Ouliaris test, and Johansen Test.

This study will use the Johansen test. It avoids the issue of choosing a dependent variable as well as matters created when errors are carried from one step to the next. Thus, the test can detect multiple cointegration vectors.

Based on the form of research, the model used is time series model with the Vector Auto Regression or Vector Error Correction Model (VECM). In the VAR model, if several variables contain the unit root and do not co-integrate with one another, then variables containing root units must be differenced. Stationary outcome variables of the differential result can be used in the VAR model. Whereas in a state of all variables containing unit root but cointegrated, the VECM can be used (Rosadi 2012).

\section{Finding and Analysis}

This section presents the empirical findings of the study with the following focus: (i) measuring the effectiveness of macroprudential instrument on reducing the credit growth for conventional bank, and (ii) measuring the effectiveness of macroprudential instrument on reducing the financing growth for sharia bank. 


\section{The Effectiveness of Macroprudential Policies in Reducing the Credit Growth}

Macroprudential Liquidity Buffer (MLB) was an improvement instrument from Secondary Reserve Requirements. The central value of MLB is the reserve requirement that has been implemented in many countries to prevent systemic risk. The effectiveness of reserve requirements was evidenced in many scientific works of literature, especially post to global financial crises occurring widely in the overheat property sector in the USA.

Generally, Countercyclical Capital Buffer (CCyB) was designed to minimize build-up of risk during good times and to increase resilience to shocks in bad times. CCyB first implemented in January 2016 through Bank Indonesia Regulation number 17/22/PBI 2015 and kept improved every six months.

In using VECM model, the stationary test should be conducted to confirm that statistical properties of time series do not change over time. The study run the Augmented Dickey-Fuller (ADF) test and Phillips-Perron (PP) test for each variable. The following table shows the result of the unit-root test with the ADF and PP test at first difference of Conventonal Bank.

Table 2. ADF and PP test result

\begin{tabular}{|c|c|c|c|c|}
\hline \multirow{2}{*}{ Variables } & \multicolumn{2}{|c|}{ ADF TEST } & \multicolumn{2}{|c|}{ PP TEST } \\
\hline & T-Statistic & Prob. & T-Statistic & Prob. \\
\hline Cr_Growth & -9.210147 & 0.0000 & -9.210147 & 0.0000 \\
\hline MLB & -10.77033 & 0.0000 & -10.77033 & 0.0000 \\
\hline ССув & -10.77033 & 0.0000 & -10.77033 & 0.0000 \\
\hline Inflations & -8.127358 & 0.0000 & -7.836627 & 0.0000 \\
\hline BI-7DRRR & -6.930639 & 0.0000 & -7.098438 & 0.0000 \\
\hline NPL & -1.416643 & 0.5715 & -10.69224 & 0.0000 \\
\hline CAR & -2.927780 & 0.0456 & -15.15915 & 0.0000 \\
\hline \multicolumn{5}{|c|}{ "Test Critical Value (MacKinnon) } \\
\hline $1 \%$ Level & \multicolumn{2}{|c|}{-3.493129} & \multicolumn{2}{|c|}{-3.487550} \\
\hline $5 \%$ Level & \multicolumn{2}{|c|}{-2.888932} & \multicolumn{2}{|c|}{-2.886509} \\
\hline $10 \%$ Level & \multicolumn{2}{|c|}{-2.581453} & \multicolumn{2}{|c|}{-2.580163} \\
\hline
\end{tabular}

Source: Data Processed (2019)

The result shows that all variables are stationary at first different except for NPL. The T-statistic values of each variable are less than the critical value at $\alpha=1 \%, \alpha=$ $5 \%$, and $\alpha=10 \%$. Credit growth, MLB, CCyB, Inflations and BI-7 days (reserve) repo rate are stationary at $\alpha=1 \%$, while the CAR is stationary at $\alpha=5 \%$.

Moreover, the PP test indicates all variables are stationary at $\alpha=1 \%$ and all the Tstatistic shows less than its critical value. Even though the result of the ADF and PP test is slightly different, yet overall data of commercial banks passed the test. 
In addition, it is necessary to determine the lag length criteria, the ideal lag length is the smallest values as it ensures the models will be stable. The selecting of optimal lag is according to the value of Akaike Information Criterion (AIC), Schwarz Information Criterion (SC) and, Hannan-Quinn Information Criterion (HQ). Khim \& Liew (2006) showed that Akaike's information criterion (AIC) is superior to the other approaches for the estimation of the autoregressive lag length.

The table below shows the optimal lag length criteria among AIC SC and, HQ for Conventional bank.

Table 3. Lag length optimal for Conventional Bank

\begin{tabular}{rlcc}
\hline \hline Lag & AIC & SC & HQ \\
\hline \hline 0 & 34.09418 & 34.26409 & 34.16312 \\
1 & 21.17987 & $22.53912^{*}$ & $21.73136^{*}$ \\
2 & $21.10641^{*}$ & 23.65501 & 22.14046 \\
\hline \hline
\end{tabular}

Source: Data Processed (2019)

The table above shows the value of each criterion, the $\left(^{*}\right)$ indicates the smallest amounts of each criterion. The lowest value of the AIC criterion is on the second lag, while SC and HQ criteria are on the first lag. However, this study will consider the AIC criterion with the second lag as the optimal lag because it provides the lowest standard among them.

From these results, it is necessary to test Johansen Cointegration Test to see the cointegration of variables in research in the long run. Johansen's approach derives two likelihood estimators for the CI rank; trace test and maximum eigenvalues test. The null hypothesis indicates no-cointegration relation between the variables and the alternative hypothesis. The rejection of the null hypothesis is indicated by the asterisk sign $\left({ }^{*}\right)$, the probability value is less than or equal to 0.05 , and the Trace or Max Eigen Value is higher than 0.05 critical value. The approval of an alternative hypothesis indicates long-run relationship among the variables.

The following table shows the results of Johansen's cointegration tests on conventional banks.

Table 4. Johansen Cointegration Test Result

\begin{tabular}{cccccc}
\hline \hline $\begin{array}{c}\text { Hypothesized } \\
\text { No. of CE(s) }\end{array}$ & Eigenvalue & \multicolumn{2}{c}{ Trace } & \multicolumn{2}{c}{ Max Eigen } \\
\cline { 2 - 6 } & & Stat & $\begin{array}{c}0.05 \text { Critical } \\
\text { Value }\end{array}$ & $\begin{array}{c}\text { Stat } \\
0.05 \text { Critical } \\
\text { Value }\end{array}$ \\
\hline \hline None ${ }^{*}$ & 0.405238 & 165.2350 & 150.5585 & 59.75321 & 50.59985 \\
\hline \hline
\end{tabular}

Source: Data Processed (2019) 
The trace test in indicates the existence of three cointegrating equations at the $\alpha=5 \%$ significance level. The trace statistic and Max Eigenvalue test confirms the value is higher than its 0.05 critical value. Therefore, those two tests ensure a cointegrating equation among the variables and have a long-run relationship. To interpret these results, we run the normalized cointegrating coefficient that allows to see the long-run relationship among the variables. Maggiora \& Skerman (2009) explained that due to the normalization process, the signs are reserved to enable proper interpretations. This table below depicts the result of normalized cointegration test of conventional bank.

Table 5. Result of normalized cointegration test for conventional bank

\begin{tabular}{|l|c|c|c|}
\hline \multicolumn{1}{|c|}{ Variables } & Coefficient & Std. Error & T-Statistic \\
\hline \hline \multicolumn{2}{|c|}{ The Normalized Cointegration Test in Conventional Bank } \\
\hline Cr. Growth & 1.000000 & & \\
\hline LB & -2.327331 & 0.49080 & $-4.74187^{*}$ \\
\hline CCyB & 1.322752 & 0.77683 & 1.70277 \\
\hline Inflations & 0.035873 & 0.11522 & 0.31134 \\
\hline BI-7DRRR & 0.691207 & 0.19098 & $3.61932^{*}$ \\
\hline NPL & $3.42 \mathrm{E}-05$ & $1.5 \mathrm{E}-05$ & $2.26873^{*}$ \\
\hline CAR & -1.053047 & 0.20886 & $-5.04198^{*}$ \\
\hline \hline
\end{tabular}

Source: Data Processed (2019)

From the result above, the cointegrating equation in the long-run model is given by the following equation:

$$
\begin{gathered}
E C T_{t-1}=\left(1.000 \text { Cr }_{\text {Growth }_{t-1}}+-2.33 M L B_{t-1}+1.32 C C y B_{t-1}+0.03 \text { Inflations }_{t-1}\right. \\
\left.+0.691 \text { BI }_{7 D R R R_{t-1}}+3.421 \text { LNNPL }_{t-1}-1.05 C A R_{t-1}+8.845\right)
\end{gathered}
$$

In this study, the normalized cointegrating coefficient test shows that the implementations of MLB will significantly increase $2.32 \%$ of credit growth at the long-run relationship. This result is caused by the implementation of MLB is still in improvements to provide a high impact. It is a fact that MLB regulations are always regenerate. Since first implemented in July 2018, this instrument got an amendment for three times.

In overall, we can assume that the MLB instrument is not capable in decreasing credit growth. The result implies that MLB is disable to minimize the potency for risk build-up in the long run, this instrument is not effective. This study revealed that reserve minimum liquidity regulated by Bank Indonesia needs an improvement to get proper policy as a macroprudential instruments. The incapable of MLB in reducing the credit growth due to the rate $4 \%$ is still low. Thus, when the economic was in good performance, the rate must be increased to reserve more securities as a 
buffer. The failure of MLB in reducing the credit growth also triggered by the rate $4 \%$ of buffer, it can be used in the purchasing agreement in terms of open market operations. Therefore, sometimes the $4 \%$ buffers not used as a reserve capital in expansion phase, but it was used in the open market operations.

The previous research on MLB is slightly conducted, but for reserve requirements topic, the result shows the same result. A study conducted by Sakti et al. (Sakti et al. 2018) and Puspitasari (Puspitasari 2016) concluded that reserves requirement has a positive impact on credit growth and not capable in mitigating the systemic risk. It implies that when the instrument implemented, the financial sector will respond to decrease the credit allocation.

The CCyB shows the opposite result. The normalized cointegration result revealed that $\mathrm{C} C \mathrm{BB}$ has a negative impact on credit growth in the long term. But the probability value was more than $\alpha=10 \%$, or the T-statistic is less than its T-Table $(1.702<1.97)$. Hence, the impact of CCyB to credit growth is not significant. In the further, the $\mathrm{CCyB}$ rate must be increased if economics were in good performance. Therefore, this instrument can be usefull in mitigating the systemic risk in significant impact.

This result implies that, the implementation of CCyB is effective in mitigating the systemic risk. CCyB Instruments is an additional capital used as a buffer to mitigate losses when there is excessive credit growth. Thus, additional capital that must form during the expansion period can be used when the condition of contraction in the economic growth. Hessou and Lai (2018) and Dana (Dana 2018) confirm that $\mathrm{CCyB}$ is used to mitigate procyclical credit growth.

The estimation also revealed the macroeconomic factors, the inflation has a negative impact on credit growth in the long-run relationships. A $1 \%$ increase in inflation decreases by $0.035 \%$ of credit growth. The increase of inflations leads the Bank in reducing the credit allocations. The increase of inflations will reduce the purchasing power of society, either for consumption, investments, including for payback the loans. Thus, the increase of inflations causes the potency of the high rate of non-performing loan, so the bank will reduce in credit allocation (Kurnianingrum 2015).

BI-7 days (reserve) repo rate shows the similar result. The normalized cointegrating coefficient revealed that BI-7DRRR has a negative significant impact on credit growth. The $1 \%$ rise in BI-7DRRR will decrease the $0.69 \%$ of credit growth in the long-run relationship. The results consistence with the classic theory that revealed the higher the interest rate, then the desire to invest is also smaller, the reason being that an entrepreneur will increase his investment expenditure if the expected return on investment is greater than the interest rate that must be paid for 
the investment fund as the cost of using the fund (cost of capital).

The Internal-Bank Factors, the normalized cointegration result shows that NPL has a negative impact on credit growth. A 1\% increase in NPL leads to a decrease of $3.42 \%$ of credit growth. This result shows that NPL negatively affects credit growth. The decrease in credit growth revealed that banks would not tough enough to the higher risk triggered the build-up of systemic risk. Hence, we can conclude that credit growth is negatively affected by NPL.

The CAR variable shows capital availability in banks. The higher the bank's adequacy capital, the greater the liquidity that can be used to be allocated for third parties. This study revealed that CAR has a positive impact on credit growth. A $1 \%$ increase in CAR leads to a rising of $1.053 \%$ of credit growth.

\section{The Effectiveness of Macroprudential Policies in Reducing the Financing Growth}

Indonesia is known as a country with a dual banking system, comprising conventional banks, and Sharia banks. Thus, Bank Indonesia regulated all the policies for this dual banking system, including macroprudential liquidity buffer. To see the result, the study run the similar stage as it done for conventional bank. To begin with, the result of unit-root test with the ADF and PP test at first difference of Sharia bank is displayed below.

Table 6. ADF and PP test result of Sharia Bank

\begin{tabular}{lcccc}
\hline \multicolumn{1}{c}{ Variables } & \multicolumn{2}{c}{ ADF TEST } & \multicolumn{2}{c}{ PP TEST } \\
& T-Statistic & Prob. & T-Statistic & Prob. \\
\hline \hline Fin_Growth & -6.166416 & 0.0000 & -51.68389 & 0.0001 \\
MLB & -10.77033 & 0.0000 & -10.77033 & 0.0000 \\
CCyB & -10.77033 & 0.0000 & -10.77033 & 0.0000 \\
Inflations & -8.127358 & 0.0000 & -7.836627 & 0.0000 \\
BI-7DRRR & -6.930639 & 0.0001 & -7.098438 & 0.0000 \\
NPF & -5.729295 & 0.0000 & -13.72783 & 0.0000 \\
CAR & -5.814845 & 0.0000 & -12.86979 & 0.0000 \\
\hline \hline & Test Critical Value (MacKinnon) & \\
\hline 1\% Level & -3.490210 & -3.487550 \\
5\% Level & -2.887665 & -2.886509 \\
10\% Level & -2.580778 & -2.580163 \\
\hline \hline
\end{tabular}

Source: Data Processed (2019)

Then, the following process is to determine the lowest values as the ideal lag length. Same as conventional bank data, the criteria is considered by three measurements, od Akaike Information Criterion (AIC), Schwarz Information 
Criterion (SC) and, Hannan-Quinn Information Criterion (HQ). The table below shows the optimal lag length of Sharia bank.

Table 7. Lag length optimal for Sharia Bank

\begin{tabular}{rlll}
\hline \hline Lag & AIC & SC & HQ \\
\hline \hline 0 & 31.77096 & 31.94086 & 31.83989 \\
1 & $18.97679^{*}$ & $20.33604^{*}$ & $19.52828^{*}$ \\
\hline \hline
\end{tabular}

Source: Data Processed (2019)

Table above shows the optimal lags for Sharia bank is at the first lag. It implies that VECM estimation in the first lag shows the relationship between financing growth and independent variables. To see the cointegration among the variables in the longterm relationship, the study employees Johansen's approach to derives two likelihood estimators for the CI rank; trace test and maximum eigenvalues test. The result is displayed by the following table.

Table 8. Johansen Cointegration Test Result

\begin{tabular}{cccccc}
\hline \hline $\begin{array}{c}\text { Hypothesized } \\
\text { No. of CE(s) }\end{array}$ & Eigenvalue & \multicolumn{2}{c}{ Trace } & \multicolumn{2}{c}{ Max Eigen } \\
\cline { 2 - 6 } & & Stat & $\begin{array}{c}0.05 \text { Critical } \\
\text { Value }\end{array}$ & $\begin{array}{c}\text { Stat } \\
0.05 \text { Critical } \\
\text { Value }\end{array}$ \\
\hline \hline None ${ }^{*}$ & 0.474141 & 162.6118 & 125.6154 & 74.55584 & 46.23142 \\
\hline \hline
\end{tabular}

Source: Data Processed (2019)

Table 8 above presents one (1) cointegrating equation. Both trace statistic value and Max Eigenvalue test exceeds the 0.05 critical value. It is indicated that the null hypothesis of no co-integration is rejected. Therefore, those two tests allow the study to analyze long-run relationship through normalized co-integration test. Table below shows the result of normalized cointegration test of sharia bank.

Table. 8 The Result of normalized cointegration test in sharia bank

\begin{tabular}{|l|l|l|l|}
\hline \hline \multicolumn{1}{|l|}{ Variables } & Coefficient & Std. Error & T-Statistic \\
\hline \multicolumn{4}{|l|}{ The Normalized Cointegration Test in sharia Bank } \\
\hline Finan. Growth & 1.000000 & & \\
\hline MLB & 0.854560 & 0.45824 & 1.86488 \\
\hline CCyB & -0.388626 & 0.52484 & -0.74046 \\
\hline Inflations & 0.135906 & 0.09247 & 1.46980 \\
\hline BI-7DRRR & 0.095851 & 0.16517 & 0.58033 \\
\hline NPF & 0.000363 & $4.8 \mathrm{E}-05$ & $7.61271^{*}$ \\
\hline CAR & -0.104832 & 0.06888 & -1.52188 \\
\hline \hline
\end{tabular}

Source: Data Processed (2019)

From the result above, the cointegrating equation in the long-run model is given by the following equation: 


$$
\begin{array}{r}
E C T_{t-1}=\left(1.000 \text { Fin_Growth }_{t-1}+0.854 M L B_{t-1}-0.388 C C y B_{t-1}+0.135 \text { Inflations }_{t-1}\right. \\
\left.+0.095 B I_{-} 7 D R R R_{t-1}+0.000363 N P F_{t-1}-0.104 C A R_{t-1}-3.910255\right)
\end{array}
$$

This study revealed that MLB in Sharia bank effectively mitigates credit growth at a value of $0.85 \%$. This result indicates that the macroprudential liquidity buffer works effectively in Sharia than in conventional banks. From the results above, we can assume that MLB is a useful instrument for Sharia Banks to prevent the build-up of systemic risk. Thus, when the economy in good condition, the potency of excessive financing growth is broad. The policymakers are already prepared for the policy to make the economy get stable.

The countercyclical capital buffer $(\mathrm{CCyB})$ shows the opposite result to a conventional bank. The normalized cointegrating coefficient shows that CCyB has a positive impact on financing growth. The coefficient value is 0.38 , and it implies that the implementation of CCyB increases by $0.38 \%$ in financing growth in long-run relationships. The result above revealed that the response of financing and credit growth to $\mathrm{CCyB}$ is not capable of minimizing the potency of risk build-up. This instrument only useful in the initial period and not continuously. This study revealed that the additional capital in Sharia banks still have a low impact on mitigating the systemic risk. It is an evaluation for Bank Indonesia to increase the CCyB rate for furher policy taken.

Moreover, Macroeconomics factors were examined as a proxy for economic performance. Macroprudential policies are commonly employed in excellent economic performance. Thus, the policy is expected to prevent the build-up of systemic risks. In this study, we run two macroeconomic factors comprising inflations and BI-7 days (reserve) repo rate.

The result revealed that inflation has a negative impact on financing growth. It implies that inflation provides the same impulse as in conventional banks. A 1\% rise in inflation leads to a decrease of 0.13 of financing growth in the long-run relationship. The results are consistent with a study conducted by Sakti et al. (Sakti et al. 2018) concluded that inflation negatively affected the financing growth in the long-run relationship.

The BI-7DRRR shows a similar impact to conventional banks. The BI-7DRRR has a negative impact on financing growth in the long-run relationship. Even though the BI-7DRRR has an indirect effect on financing, the margin rate in Sharia banks is commonly in line with a reference interest rate in conventional banks. When the BI7DRRR is low, the margin rate in Sharia banks has a capability to compete, while in the high rate of BI-7DRRR, it will decrease the financing allocation in Sharia Banks. It 
implies that the theory of displaced commercial risk is not capable in describing the result. It due to the amount of customer and capital owned by conventional bank is far from Sharia Bank. Hence, Sharia bank still cannot be the major competitor for conventional bank. This result revealed that financing in Sharia bank also affected by interest rate.

For the internal-bank factors, the normalized cointegrating test shows that NPF has a negative impact on financing growth. An increase of NPF leads to a decrease of $0.000363 \%$ in financing growth. While CAR has a positive impact on financing growth. A $1 \%$ increase in CAR leads to a rising $0.104 \%$ in credit growth.

\section{Conclusion}

Refers to several approaches estimated before, the conclusions are mentioned below:

a. The MLB policy has a positive significant impact on credit growth while in the Sharia Bank, MLB shows the opposite result. Hence, we can conclude that the implementation of the MLB policy effectively mitigates the build-up of systemic risk only in Sharia bank.

b. The CCyB policy presents the different impact from MLB. The CCyB has a negative impact on credit growth, while for Sharia bank, CCyB has positive impact. Hence, we can conclude that the implementation of the CCyB policy effectively mitigates the build-up of systemic risk only in conventional bank.

c. The macroeconomic factors, Inflation has a negative impact. In other word, it effectively mitigates the systemic risk in the long-run relationship; the estimating shows a similar result in both conventional and sharia banks. The BI-7DRRR also shows the similar result in both conventional and Sharia Bank. BI-7DRRR has a negative impact on credit and financing growth. Hence, we can conclude that the increase of the Inflations and BI-7DRRR are effectively mitigated the buildup of systemic risk in both conventional and Sharia bank.

d. In the conventional bank, credit growth positively significantly affected by the NPL in the long-run relationship. While CAR has a positive significant impact on credit growth. For Sharia Bank, the NPF shows a negative significant impact on financing growth. While CAR has a positive impact on financing growth.

\section{References}

[1]Asmara, Gian Chandra. 2018. "BI Rilis Aturan Rasio Intermediasi Makroprudensial Dan PLM." CNBC Indonesia. 2018.

[2]Bank Indonesia. 2016. Mengupas Kebijakan Makroprudensial. Edited by Cicilia A 
Harun, Sagita Rachmanira, and Rani Wijayanti. First. Jakarta: Bank Indonesia.

[3]-_-. 2018. Bank Indonesia Regulation Number 20/4/PBI Dated 3 April 2018

Concerning Macroprudential Intermediation Ratios and Macroprudential Liquidity

Buffers for Conventional Commercial Banks, Sharia Commercial Banks, and Sharia Business Units. Jakarta: Bank Indonesia.

[4]Blancher, Nicolas R., Srobona Mitra, Hanan Morsy, Akira Otani, Tiago Severo, and Laura Valderrama. 2013. "Systemic Risk Monitoring ('SysMo') Toolkit-A User Guide." IMF Working Papers $13 \quad$ (168): $\quad$ i. https://doi.org/10.5089/9781484383438.001.

[5]Claessens, Stijn. 2014. “An Overview of Macroprudential Policy Tools." 14. 214. Washington DC.

[6]Claessens, Stijn, Swati R Ghosh, and Roxana Mihet. 2014. "Macro-Prudential Policies to Mitigate Financial System Vulnerabilities." 14. 155. Washington DC.

[7]Dana, Badara Shofi. 2018. "Evaluation of Macro-Prudential Policy on Credit Growth in Indonesia: Credit Registry Data Approach." Etikonomi 17 (2): 199-212. https://doi.org/doi: http//dx.doi.org/10.15408/etk.v17i2.7324.

[8]Fauziyyah, Neneng Ella. 2016. “Analisis Dampak Kebijakan Pelonggaran Financing to Value (FTV) Terhadap Penyaluran Pembiayaan Property Di Perbankan Syariah Dalam Kerangka Kebijakan Makroprudensial." State Islamic University Sunan Kalijaga.

[9]Fendoglu, Salih. 2017. "Credit Cycles and Capital Flows: Effectiveness of the Macroprudential Policy Framework in Emerging Market Economies." Journal of $\begin{array}{llll}\text { Banking } & \text { Finance } & 79 & \text { (March): }\end{array}$ https://doi.org/10.1016/j.jbankfin.2017.03.008.

[10]Hahm, Joon-ho, Frederic S Mishkin, Hyun Song Shin, and Kwanho Shin. 2012. "Macroprudential Policies In Open Emerging Economies." 17780. Cambridge.

[11]Harun, Cicilia A, Sagita Rachmanira, and Raquela Renanda. 2015. "Kerangka Pengukuran Risiko Sistemik." 4. Jakarta.

[12]IMF. 2011. “Macroprudential Policy: An Organizing Framework." International Monetary Fund, March 2011.

[13]Jimenez, Gabriel, Steven Ongena, Jesus Saurina, and Jose-Luis Peydro. 2012. "Macroprudential Policy, Countercyclical Bank Capital Buffers and Credit Supply: Evidence from the Spanish Dynamic Provisioning Experiments." 231. Brussels.

[14]Khim, Venus, and Sen Liew. 2006. "Which Lag Length Selection Criteria Should We Employ." Economics Bulletin 3 (33): 1-9.

[15]Kurnianingrum, Dian. 2015. "The Influence of Bi Rate to the Distribution of Working Capital Loans." Binus Business Review 6 (3): 356. https://doi.org/10.21512/bbr.v6i3.945.

[16]Maggiora, Daniel Della, and R Skerman. 2009. "Johansen Cointegration Analysis of American and European Stock Market Indices: An Empirical Study." School of Economics and Management Lund University. Lund University.

[17]Purnawan, Muhammad Edhie, and M Abd Nasir. 2015. "The Role of 
Macroprudential Policy to Manage Exchange Rate Volatility, Excess Banking Liquidity and Credits." Bulletin of Monetary Economics and Banking, July 2015.

[18]Puspitasari, Intan. 2016. "Efektifitas Kebijakan Makroprudensial Dalam Memitigasi Prosiklikalitas Kredit Dan Pembiayaan Dual Banking System Di Indonesia." IOSR Journal of Economics and Finance. UIN Sunan Kalijaga Yogyakarta. https://doi.org/https://doi.org/10.3929/ethz-b-000238666.

[19]Rosadi, Dedi. 2012. Ekonometrika Dan Analisis Runtun Waktu Terapan. Yogyakarta: Penerbit ANDI.

[20]Sakti, Muhammad Rizky Prima, Hassanudin bin Mohd Thas Thaker, Abdul Qoyum, and Ibnu Qizam. 2018. “The Concept and Practices of Macroprudential Policy in Indonesia: Islamic and Conventional." Al-Iqtishad: Journal of Islamic Economics 10 (January): 75-96.

[21]Shi, Song, Jyh-bang Jou, and David Tripe. 2014. "Can Interest Rates Really Control House Prices? Effectiveness and Implications for Macroprudential Policy." Journal of Banking Finance 47: 15-28. https://doi.org/10.1016/j.jbankfin.2014.06.012.

[22]Ubaidillah, Ahmad Kholid. 2019. “Effektifitas Kebijakan Makroprudensial Sebagai Countercyclical Penyaluran Kredit Dan Pembiayaan Perbankan Di Indonesia." UIN Sunan Kalijaga.

[23]Widarjono, Agus. 2013. Ekonometrika Pengantar Teori Dan Aplikasinya. Fifth Edit. Yogyakarta: Ekonosia-FE UII. 